\title{
GAGASAN PENERAPAN VICARIOUS LIABILITY DALAM KONSEP KUHP ATAS TINDAK PIDANA YANG DILAKUKAN ANAK
}

\author{
I.Gst Ngr Hady Purnama Putera \\ Fakultas Hukum Universitas Gadjah Mada \\ Email : purnama623@gmail.com
}

\begin{abstract}
ABSTRAK
Pendekatan penegakan hukum pidana Indonesia dewasa ini yang menekankan kepada pelaksanaan restorative justice membuka pintu-pintu baru untuk pembaharuan hukum pidana indonesia, penulis berpandangan bahwa sekat yang selama ini ada antara hukum pidana yang bersifat publik dan hukum perdata yang bersifat prifat bisa menjadi sebuah jembatan jika di manfaatkan secara baik demi pembaharuan hukum pidana tersebut. Tindak pidana yang dilakukan oleh anak yang secara hukum di bawah umur untuk dikatakan cakap secara hukum, sering kali terjadi karena adanya pergeseran konstruksi sosial di masyarakat yang mendorong anak melakukan tindak-tindak pidana tersebut. Permasalahan tindak pidana oleh anak tersebut akan membawa pada pertanyaan bagaimana ia akan mempertanggungjawabkannya, pun hukum pidana sudah memiliki konstruksi penegakan hukum pidana anak dalam sistem hukumnya, penulis masih merasa penegakan hukum pidana anak masih dapat dikembangkan dalam konsep pembaharuan hukum pidana, dan penulis datang dengan sebuah gagasan tentang pertanggungjawaban pengganti atau yang dalam bahasa aslinya dikenal sebagai vicarious liability. Vicarious liability adalah pertanggungjawaban menurut hukum seseorang atas perbuatan salah yang dilakukan oleh orang lain (the legal responsibility of one person for the wrongful acts of another). Secara singkat vicarious liability sering diartikan sebagai "pertanggungjawaban pengganti".
\end{abstract}

Kata kunci : restorative justice, hukum pidana, vicarious liability

\begin{abstract}
Nowdays Indonesian Penal System is developed to the restorative justice as the result for the penal system. This consept open the posibility for the regenarate the indonesian penal system. The author think that tha gap between penal and private legal system in indonesia can be a good bridge for this regeneration of the penal system. For a case the outlaw act that commited by the unlawful act children was a problem during the prosecution act. This outlaw act that conducted by the children in many case was caused because of the shifting norm in the society. Indonesian penal system nowdays already have their own ways to prosecute this child in the criminal case that they commited to do, even though the outher still belive that we can regenerate the whole new ways to handle this case, one of thoose ways that the author bring to this paper was vicarious liability. The vicarious liability origyn was taken from the indonesian private law field that the author try to infuse into the penal system during this case. How this whole strange consep can make their own way will be elaborate in this paper.
\end{abstract}

Keywords: restorative justice, criminal law, vicarious liability 


\section{Pendahuluan}

Perkembangan jaman dan kemajuan teknologi serta media masa, ditambah tekanan hidup yang semakin tinggi di masyarakat tidak dapat dipungkiri memberi pengaruh negatif pada perkembangan anak di lingkungan khususnya di wilayah perkotaan, faktor eksternal tadi juga ditambah dengan kurangnya perhatian orang tua dalam mengawasi anak-anak. Dalam hal pandangan ini terdapat pendapat yang senada dengan hal tersebut seperti apa yang disampaikan Gatot Supramono

"Penyimpangan tingkah laku atau perbuatan melanggar hukum yang dilakukan oleh anak disebabkan oleh berbagai faktor antara lain adanya dampak negatif dari perkembangan pembangunan yang cepat, arus globalisasi di bidang komunikasi dan informasi, kemajuan ilmu pengetahuan dan teknologi serta perubahan gaya dan cara hidup sebagai orang tua, telah membawa perubahan sosial yang mendasar dalam kehidupan masyarakat yang sangat berpengaruh terhadap nilai dan perilaku anak. Selain itu anak yang kurang atau tidak memperoleh kasih sayang, asuhan dan bimbingan dan pembinaan dalam pengembangan sikap perilaku penyesuain diri, serta pengawasan dari orang tua, wali atau orang tua asuh akan mudah terseret dalam arus pergaulan masyarakat dan lingkungannya yang kurang sehat dan merugikan perkembangan pribadinya." (Gatot, 2000).

Masalah lain selain akar masalah mengapa anak kemudian memiliki kecenderungan melakukan tindakan yang mengarah pada pelanggaran hukum menjadi lebih kompleks, ketika anak yang bermasalah dengan hukum ini dihadapkan pada sidang pengadilan yang akan memfonis perbuatannya benar ataukah salah, layaknya efek domino stigmasi di masyarakat semakin memperparah keterpurukan masa depan dari anak yang sempat bermasalah dengan hukum, meski jika kita berkaca pada padangan tentang penyimpangan prilaku anak sebelumnya di atas, perbuatan atau perilaku menyimpang tersebut tidaklah sepenuhnya kesalahan anak.

Konsep KUHP dalam ranah pembaharuan kemudian datang dengan konsep pertanggungjawaban yang benar-benar tidak dikenal dalam hukum pidana, namun sebelumnya kerap digunakan dalam lapangan hukum perdata, yakni vicarious liability atau pertanggungjawaban pengganti. Penulis mencoba melemparkan sebuah gagasan dalam lapangan pembaharuan hukum pidana indonesia dengan menggunakan konsep yang dikenal baik dalam lapangan hukum perdata indonesia, pertanyaan yang kemudian timbul adalah berkenaan dengan bagainama prinsip pertanggungjawaban pegganti atau vicarious liability pada lapangan hukum pidana yang ditawarkan konsep KUHP akan dapat diterapkan sehingga sesuai dengan prinsip penegakan hukum pidana yang telah digunakan sebagai bagian dari sistem hukum pidana indonesia itu sendiri dan dapatkah konsep vicarious liability dalam konsep KUHP tersebut diaplikasikan dalam perkara tindak pidana anak akan menjadi fokus penulis dalam penulisan ilmiah berikut.

\section{Metode Penelitian}

Jenis penelitian yang digunakan dalam penulisan kali ini adalah jenis 
penelitian hukum normatif karena meneliti asas-asas hukum, selain itu penelitian ini juga mengkaji dan meneliti peraturan-peraturan tertulis (Soerjono Soekanto, 1986). Karena penelitian ini adalah penelitian normatif maka sumber datanya adalah berupa data sekunder yang berupa bahan hukum primer maupun bahan hukum sekunder (Amirudin dan H.Zainal Asikin, 2003). Jenis pendekatan yang digunakan dalam penelitian ini adalah pendekatan fakta, pendekatan perundangundangan dan pendekatan konsep. Serta dilakukan pula analisis terhadap bahan-bahan hukum yang didapat dengan cara deskriptif, analisis, dan argumentatif.

\section{Pembahasan}

\section{Tinjauan Umum Tentang Tindak Pidana Anak}

Perlu dipahami sebelumnya, kedudukan anak dalam lingkungan hukum sebagai subyek hukum ditentukan dari sistem hukum terhadap anak sebagai kelompok masyarakat yang berada di dalam status hukum dan tergolong tidak mampu atau di bawah umur. Maksud tidak mampu karena kedudukan akal dan pertumbuhan fisik yang sedang berkembang dalam diri anak yang bersangkutan. Meletakkan anak sebagai subyek hukum yang lahir dari proses sosialisasi berbagai nilai ke dalam peristiwa hukum pidana maupun hukum hubungan kontrak yang berada dalam lingkup hukum perdata menjadi mata rantai yang tidak dapat dipisahkan (Wadong, 2000).

Kemudian tentang tindak pidana anak sendiri tidak secara tegas disebut baik dalam UndangUndang Nomor 3 Tahun 1997 tentang
Pengadilan Anak, dalam rumusan pasal Undang-Undang tersebut hanya dijelaskan tentang anak nakal yang diatur dalam pasal 1 butir 2, yang menyatakan anak nakal adalah:

a. Anak yang melakukan tindak pidana, atau

b. Anak yang melakukan perbuatan yang dinyatakan dilarang bagi anak, baik menururt peraturan perundang-undangan maupun menurut peraturan hukum lain yang hidup dan berlaku dalam masyarakat yang bersangkutan.

Sementara dalam UndangUndang Nomor 11 tahun 2012 tentang Sistem Peradilan Anak, bahasa yang digunakan adalah anak yang berkonflik dengan hukum sebagaimana diatur dalam pasal 1 butir 2 sebagai berikut: "Anak yang Berkonflik dengan Hukum yang selanjutnya disebut Anak adalah anak yang telah berumur 12 (dua belas) tahun, tetapi belum berumur 18 (delapan belas) tahun yang diduga melakukan tindak pidana."

Kedua rumusan pasal dari dua Undang-Undang yang berbeda tadi seperti yang telah penulis paparkan sebelumnya tidak secarategas menyebut apa itu tindak pidana anak, namun demikian dari sisi praktisi hukum, apa itu tindak pidana anak dikemukakan Pula Oleh Komari (Ketua Pengadilan Negeri Yogyakarta Tahun 2009) sebagai berikut :

"Apabila terjadi pelanggaran hak anak termasuk tindak pidana umum berupa kejahatan atau pelanggaran yang dilakukan oleh anak maka diklasifikasikan sebagai tindak pidana anak. Oleh karena itu pemakalah berpendapat tindak pidana anak adalah tindak pidana yang dilakukan oleh anak, yang berumur 8 tahun tetapi belum 
berumur 18 tahun dan belum kawin atau yang melakukan perbuatan yang dinyatakan terlarang bagi anak, baik menurut peraturan perundangundangan maupun peraturan hukum lain yang hidup dan berlaku dalam masyarakat yang bersangkutan." (Komari, 2009).

\section{Tinjauan Umum Tentang Vicarious Liability}

Vicarious liability adalah pertanggungjawaban menurut hukum seseorang atas perbuatan salah yang dilakukan oleh orang lain (the legal responsibility of one person for the wrongful acts of another). Secara singkat vicarious liability sering diartikan sebagai "pertanggungjawaban pengganti". Pertanggungjawaban pengganti itu dirumuskan dalam Pasal 35 ayat (3) Konsep yang mengatur :"Dalam hal tertentu, setiap orang dapat dipertanggung jawabkan atas tindak pidana yang dilakukan oleh orang lain, jika ditentukan dalam suatu undang-undang. "

Untuk memahami lebih jauh latar dan alasan dicantumkannya asas vicarious liability ini ke dalam konsep, dapat dilihat pada penjelasannya berikut ini :

Ketentuan ayat ini merupakan pengecualian dari asas tiada pidana tanpa kesalahan. Lahirnya pengecualian ini merupakan penghalusan dan pendalaman asas regulatif dari yuridis moral yaitu dalam hal-hal tertentu tanggung jawab seseorang dipandang patut diperluas sampai kepada tindakan bawahannya yang melakukan pekerjaan atau perbuatan untuknya atau dalam batas-batas perintahnya. Oleh karena itu, meskipun seseorang dalam kenyataannya tidak melakukan tindak pidana namun dalam rangka pertanggungjawaban pidana ia dipandang mempunyai kesalahan jika perbuatan orang lain yang berada dalam kedudukan yang sedemikian itu merupakan tindak pidana. Sebagai suatu pengecualian, maka ketentuan ini penggunaannya harus dibatasi untuk kejadian kejadian tertentu yang ditentukan secara tegas oleh undangundang agar tidak digunakan secara sewenang-wenang. Asas pertanggungjawaban yang bersifat pengecualian ini dikenal sebagai asas tanggung jawab mutlak atau "vicarious liability".

Roeslan Saleh (1983) dalam bukunya mengakui adanya vicarious liability sebagai pengecualian dari asas kesalahan. Roeslan Saleh berpendapat bahwa pada umumnya seseorang bertanggung jawab atas perbuatannya sendiri. Akan tetapi ada yang disebut vicarious liability, orang bertanggung jawab atas perbuatan orang lain. Aturan undangundanglah yang menetapkan siapasiapakah yang dipandang sebagai pelaku yang bertanggung jawab.

Vicarious liability biasa digunakan dalam hukum perdata. Namun, dalam hukum pidana merupakan hal baru karena menyimpang dari asas kesalahan yang dianut selama ini. dalam hukum perdata vicarious liability diterapkan pada kasus-kasus kerugian (tort). Tort merupakan pembayaran ganti kerugian atas perbuatan yang dilakukan oleh buruh yang merugikan pihak ketiga. Akan tetapi, dalam hukum pidana konsepnya sangat berbeda. Diterapkannya hukuman (pidana) terhadap orang yang merugikan atau mengancam kepentingan sosial, sebagian untuk memperbaiki dan sebagian lagi untuk 
melindungi dan mencegah dari aktivitas yang bersifat anti social (Johny Krisnan, 2008).

Secara tradisonal konsep itu telah diperluas terhadap suatu situasi dimana pengusaha bertanggung jawab terhadap perbuatan pidana yang dilakukan oleh pegawainya dalam ruang lingkup pekerjaanya. Tanggung jawab yang dipikul oleh majikan itu dapat terjadi satu diantara tiga hal berikut ini:

1. Peraturan perundang-undangan secara eksplisit menyebutkan pertanggungjawaban suatu kejahatan secara vicarious.

2. Pengadilan telah mengembangkan "doktrin pendelegasian" dalam kasus pemberian lisensi. Doktrin itu berisi tentang pertanggungjawaban seseorang atas perbuatan yang dilakukan oleh orang lain, apabila ia telah mendelegasikan kewenangannya menurut undang-undang keapda orang lain itu. Jadi, harus ada prinsip pendelegasian.

3. Pengadilan dapat menginterprestasikan kata-kata dalam undang-undang sehingga tindakan dari pekerja atau pegawai dianggap sebagai tindakan dari pengusaha.

\section{Penerapan Vicarious Liability dalam Perkara Tindak Pidana yang Dilakukan oleh Anak}

Dari dua tinjauan umum tentang topik pembahasan penelitian kali ini dapat dilihat ada dua kutub jauh yang masih terlihat memiliki peluang untuk disatukan di masa datang sebagai sebuah upaya hukum yang dicita-citakan atau isu constituendum. Di satu sisi sistem atau prinsip pertanggungjawaban vicarious liability sangat baru digunakan di lapangan hukum pidana terlebih lagi di indonesia, dimana mekanisme penggunaannya menjadi lebih kompleks dari penggunaannya pada lapangan hukum perdata berupa pembayaran Tort atau ganti rugi, dan dalam konsep KUHP jelas menunjukan adanya ruang terbuka bilamana Undang-Undang di masa datang mengatur atau menghendaki pengalihan atau penggantian kewajiban pertanggungjawaban pidana dari seseorang kepada orang lain.

Dis sisi lain masalah peradilan anak dan tentu tindak pidana oleh anak tidak dipungkiri mengalami kesemrawutan ketika pemerintah mencabut pasal-pasal tentang anak dalam KUHP warisan $W v S$, dan bukannya memperbaiki aturan induk dalam KUHP tentang hal tersebut namun malah membuat aturan lain di luar KUHP, meski keluarnya sistem tertang peradilan anak yang diawali Undang-Undang Nomor 3 Tahun 1997 tentang Pengadilan Anak, yang kemudian diperbaharui dengan Undang-Undang Nomor 11 tahun 2012, masih memiliki ruang yang menjaga anak-anak mendapat masa depan yang masih terbuka, diantaranya dengan upaya diversi yang dengan jelas diatur pertimbangan dan mekanismenya, termasuk mempertimbangkan psikologi si anak berupa penghindaran dari stigma negatif.

Adapun diversi sebagaimana diatur dalam pasal 8 ayat (3) UndangUndang Nomor 11 Tahun 2012 Tentang Sisem Peradilan Anak menyebutkan apa yang harus dan patut dipertimbangan dalam diversi sebagai berikut.

Proses Diversi wajib memperhatikan : 
a. Kepentingan korban;

b. Kesejahteraan dan tanggung jawab Anak;

c. Penghindaran stigma negatif;

d. Penghindaran pembalasan;

e. Keharmonisan masyaraka; dan

f.Kepatutan, kesusilaan, dan ketertiban umum

Dengan dua hal tersebut dapat dilihat bahwa penggunaan prinsip vicarious liability dapat kiranya di masa datang diterapkan pada perkara tindak pidana oleh anak, selama, prinsip vicarious liability dapat diterima sepenuhnya sebagai salah satu bentuk pertanggungjawaban pidana di lapangan hukum pidana indonesia di masa yang akan datang, serta adanya perbaikan dalam Undang-Undang atau peraturan yang berkaitan dengan tindak pidana yang dilakukan anak di masa depan yang mencantumkan adanya prinsip pertanggungjawaban pengganti atau vicarious liability tersebut, dan dibarengi pembinaan kepada anak yang berkonflik dengan hukum sehingga tidak ada pengulangan tindak pidana di masa mendatang, dan tentu saja memperhatikan kepentingan korban dan masyarakat sebagai bentuk restorative justice. merupakan pengecualian dari asas tiada pidana tanpa kesalahan.

\section{Kesimpulan}

Vicarious liability adalah pertanggungjawaban menurut hukum seseorang atas perbuatan salah yang dilakukan oleh orang lain (the legal responsibility of one person for the wrongful acts of another). Secara singkat vicarious liability sering diartikan sebagai "pertanggungjawaban pengganti". Pertanggungjawaban pengganti itu dirumuskan dalam Pasal 35 ayat (3) Konsep KUHP. Vicarious liability juga merupakan merupakan pengecualian dari asas tiada pidana tanpa kesalahan, maka ketentuan ini penggunaannya harus dibatasi untuk kejadian kejadian tertentu yang ditentukan secara tegas oleh undangundang agar tidak digunakan secara sewenang-wenang.

Vicarious liability di masa depan dapat diharapkan sebagai sebuah alternatif sistem pertanggungjawaban pidana dalam perkara tindak pidana oleh anak, asalkan prinsip vicarious liability dapat diterima sepenuhnya sebagai salah satu bentuk pertanggungjawaban pidana di lapangan hukum pidana indonesia di masa yang akan datang, serta adanya perbaikan dalam Undang-Undang atau peraturan yang berkaitan dengan tindak pidana yang dilakukan anak di masa depan yang mencantumkan adanya prinsip pertanggungjawaban pengganti atau vicarious liability tersebut, dan dibarengi pembinaan kepada anak yang berkonflik dengan hukum sehingga tidak ada pengulangan tindak pidana di masa mendatang, dan tentu saja memperhatikan kepentingan korban dan masyarakat sebagai bentuk restorative justice.

\section{Daftar Pustaka}

Amirudin dan H.Zainal Asikin, 2003, Pengantar Metode Penelitian Hukum, PT. Raja Grafindo Persada, jakarta.

Johny Krisnan, 2008, Sistem pertanggungjawaban Pidana dalam Perspektif Pembaharuan Hukum Pidana Nasional, Thesis, Fakultas Hukum Universitas Diponegoro, Semarang. 
Komari, 2009, Dasar Pertimbangan Hukum Hakim Dalam Mengadili Dan Mememutus Perkara Pelanggaran Hak Anak Dan Tindak Pidana Anak, makalah Disampaikan pada : Seminar Nasional "Optimalisasi Perlindungan Anak danTantangannya di Indonesia" Atas Kerjasama Universitas Atmajaya Yogyakarta, UNICEF dan Kejaksaan Agung Republik Indonesia Yogyakarta, 29 Oktober 2009, ( cited 20134 january ), Available from URL http://www.pnyogyakota.go.id/pnyk/infohukum.html

Maulana Hasan Wadong, 2000, Advokasi dan Hukum Perlindungan Anak, Gramedia Wina Sarana, Jakarta.

Roeslan Saleh, 1983, Suatu Reorienasi dalam Hukum Pidana, Aksara Baru, Jakarta.

Soerjono Soekanto, 1986, Pengantar Penelitian Hukum, UI-Press, jakarta.

Sumpramono Gatot, 2000, Hukum Acara Pengadilan Anak, Djambatan, Jakarta.

Undang - Undang Nomor 3 tahun 1997 Tentang Pengadilan Anak, Tambahan Lembaran Negara Republik Indonesia Nomor 3668.

Undang-Undang Nomor 11 Tahun 2012 tentang Sistem Peradilan Anak, Tambahan Lembaran Negara Republik Indonesia Nomor 5332. 